\title{
Victims and Criminal Justice: What's Next?
}

Michael M. O'Hear

Marquette University Law School, michael.ohear@marquette.edu

Follow this and additional works at: http://scholarship.law.marquette.edu/facpub

Part of the Law Commons

Publication Information

Published as Michael M. O'Hear, Victims and Criminal Justice: What's Next?, 19 Fed. Sent'g Rep. 83 (2006). (C) 2006 by the Regents of the University of California on behalf of the Vera Institute of Justice. Copying and permissions notice: Authorization to copy this content beyond fair use (as specified in Sections 107 and 108 of the U. S. Copyright Law) for internal or personal use, or the internal or personal use of specific clients, is granted by the Regents of the University of California on behalf of the Vera Institute of Justice for libraries and other users, provided that they are registered with and pay the specified fee via Rightslink ${ }^{\circledast}$ on Caliber (http://caliber.ucpress.net/) or directly with the Copyright Clearance Center, http://www.copyright.com.

\section{Repository Citation}

O'Hear, Michael M., "Victims and Criminal Justice: What's Next?" (2006). Faculty Publications. Paper 115.

http://scholarship.law.marquette.edu/facpub/115

This Article is brought to you for free and open access by the Faculty Scholarship at Marquette Law Scholarly Commons. It has been accepted for inclusion in Faculty Publications by an authorized administrator of Marquette Law Scholarly Commons. For more information, please contact 


\section{EDITOR'S OBSERVATIONS}

\section{Victims and Criminal Justice: What's Next?}

\section{MICHAEL M. O'HEAR}

Associate Professor, Marquette University Law School Editor, Federal Sentencing Reporter

The victims' rights movement has proven remarkably successful in the political arena. ${ }^{\mathrm{I}}$ The success is due, in part, to popular stereotypes of "good" victims and "bad" defendants, as well as to a legislative reform program that emphasizes giving victims procedural rights analogous to those of defendants. ${ }^{2}$ These reforms are, in a sense, "easy." They do not require a dramatic restructuring of criminal procedure, but only new opportunities for victims to be heard within the existing procedural framework. The costs of such procedural rights are subtle and-given common perceptions of victim-offender relationships as strictly adversarial—may be seen as falling most heavily on criminals, a social group that is, almost by definition, unpopular and politically disenfranchised. Conceived this way, victims' rights can draw strength from the public's seemingly insatiable desire to express hostility to criminals through legislation. ${ }^{3}$

To be sure, reforms that are politically easy to adopt may nonetheless prove difficult to implement. It is one thing for a politician to speak grandly of "counterbalanc[ing]" defendants' rights, 4 but quite another for the judiciary to figure out exactly how much weight to add to the scales in a host of different contexts, taking into account constitutional norms of due process and equal protection, practical resource constraints, and the many other legislative mandates imposed on the criminal justice system. ${ }^{5}$ These sorts of challenges, particularly the difficulties in implementing hearing rights for victims within the existing procedural framework of federal sentencing, were the principal subject of the last issue of FSR. Articles covered such topics as the permissible number and content of victim impact statements for capital sentencing purposes, ${ }^{6}$ the extent to which different kinds of victim impact statements give rise to strong emotional responses that may impair the rationality of sentencing decisions, 7 the right of victims to deliver an oral (as opposed to a written) statement at sentencing, ${ }^{8}$ and the mechanism for victims to appeal adverse decisions regarding their hearing rights. 9

The present issue of FSR includes additional coverage of such issues (for instance, the question of whether victims should have a right to review presentence reports ${ }^{\mathrm{IO}}$ ) but also contains approaches to the victim's role that go beyond enhanced hearing rights and point the way to a more profound rethinking of criminal justice. If the last issue focused on the implications of adding the voice of victims to the chorus at sentencing, then this issue questions whether a genuine commitment to victims' well-being requires that a whole new melody be sung. The victims' movement, however, cannot be viewed in this transformative manner without first calling into question the absolutist "good victim/bad offender" stereotype, the perception of strict adversity between victims and offenders, and the equation of victim preferences with the maximization of punishment.

In these Editor's Observations, I first survey the contributions to this issue, particularly highlighting the extent to which a diverse set of authors casts doubt on common stereotypes of victims and suggest reforms that go beyond basic hearing rights. I then conclude with my own reflections on why the emergence of a powerful victims' rights movement might be viewed as a hopeful development, even by those whose overriding perspective on American criminal justice is a concern with the system's extraordinary harshness to defendants.

Federal Sentencing Reporter, Vol. I9, No. 2, pp. 83-90, ISSN I053-9867 electronic ISSN $1533-8363$ (C) 2006 Vera Institute of Justice. All rights reserved. Please direct requests for permission to photocopy or reproduce article content through the University of California Press's Rights and Permissions website, http://www.ucpressjournals.com/reprintInfo.asp. DOI: fsr.2006.I9.2.83. 


\section{Beyond the Stereotypes: A More Complete Picture of Victim Needs and Preferences A. Victims and Severity}

In her contribution to this issue, Myrna Raeder draws our attention to the victims of domestic violence. ${ }^{\text {II }}$ She canvasses the legal bases for federalizing such crimes and identifies some of the particular issues facing victims of domestic abuse in the federal forum. She notes the pervasive phenomenon of domestic violence victims refusing to cooperate with the prosecution of their abusive partners (belying the stereotype of strict victim-offender adversity) ${ }^{12}$ and rejects an absolute rule either for or against victim control over the decision to prosecute. ${ }^{13}$ She also discusses the troubling reality that many criminal offenses committed by women are connected to abuse they have suffered at the hands of family members and intimate partners. ${ }^{14}$ Such cases encompass not only the muchdiscussed phenomenon of women killing their abusers but also situations in which abusers have, in some sense, coerced their victims to participate in other criminal activities. These sorts of cases dramatically undermine the good victim/bad offender stereotype and, in Raeder's view, should prompt the victims' rights movement to advocate "for a more sensitive sentencing regime." ${ }^{5}$ Women, she argues, "should not lose their status as victims of domestic violence when judges determine their sentence simply because they have acquired another status, that of offender." ${ }^{6}$

Marilyn Peterson Armour and Mark Umbreit question what really best serves the healing needs of one class of particularly sympathetic victims, the family members of those who have been murdered. ${ }^{17}$ Their emphasis on healing and recovery is at once intuitively compelling and oddly dissonant in the context of American criminal justice. Yet, as Armour and Umbreit observe, the emotional needs of victims have long played a prominent role in the political rhetoric surrounding capital punishment, which is often justified on the basis of the family's need for "closure." Assessing the social scientific literature, Armour and Umbreit conclude that much research must still be done to determine what sort of "closure," if any, is really desired by victims; how the criminal justice system can best deliver closure; and how closure relates to healing. Along the way, Armour and Umbreit cast doubt on the assumption that the interests of murder victims really are best served by imposing the ultimate penal sanction. ${ }^{18}$

\section{B. Meeting Victim Needs in the Criminal Justice System}

Susanne Walther offers an international perspective, describing recent developments affecting victims in the German court system. ${ }^{19}$ Germany has, in many respects, acted more aggressively and creatively in addressing victim needs than most American jurisdictions. Perhaps most notable is the extent to which the German system rejects the traditional American view that prosecutors provide adequate representation of victim interests. German victims, for instance, are offered independent legal representation at state expense in a number of circumstances ${ }^{2 \circ}$ and, in about 20 percent of serious cases, have the opportunity to act as "collateral prosecutor." 21 The latter status provides victims with a wide array of procedural rights that are usually limited to parties, such as rights to challenge the admissibility of evidence, confront witnesses, and make a closing argument. ${ }^{22}$ The German recognition of victims as independent parties with interests potentially divergent from those of prosecutors reflects, in part, the fact that Germany does not have an American-style adversarial system of criminal procedure. ${ }^{23}$ But, according to Walther, victims' rights in Germany also embody an acknowledgment that "criminal justice cannot be abstract from the spheres of reality," and that victim interests must be integrated into the traditional theoretical foundations of punishment (retribution, deterrence, and prevention). ${ }^{24}$

Judge Paul Cassell makes several appearances in this issue, first as the author of an article advocating for a new federal "anti-profiting" statute. ${ }^{25}$ While such a statute-which would prevent high-profile federal offenders from trading on their notoriety for financial benefit-might be implemented in a way that has no direct bearing on victims, Cassell structures his proposal such that victims themselves may initiate proceedings to forfeit impermissible profits and then have them applied to satisfy outstanding restitution awards. ${ }^{26}$ "A crime," he asserts, "should result in punishment for the offender and restitution for victims" 27 -and he is apparently unwilling to leave the latter objective to prosecutors alone. His proposal thus resonates with Walther's account of the German system. Indeed, Walther reports that reparation has been high on the German reform agenda in recent years and observes that German victims are permitted to "attach" civil tort claims to criminal proceedings. ${ }^{28}$ Cassell and Walther both remind us, at least implicitly, that victims often have pressing financial needs-needs that may overshadow, or even be flatly inconsistent with, a victim's desire for a sentence of imprisonment. ${ }^{29}$ 
Benji McMurray is also thinking about financial reparations, as well as the more intangible benefits of an apology. $3^{\circ} \mathrm{He}$ argues that an offender's apology and voluntary efforts to ameliorate the harm he has caused should result in a mitigated sentence. He believes that victim-offender reconciliation should be encouraged because it offers healing-related benefits to both victims and offenders. Indeed, he suggests that the benefits are so important that defense lawyers may have something of an ethical obligation to encourage their clients to pursue reconciliation even in the absence of clear sentencing benefits. ${ }^{3 \mathrm{I}}$

Erin Ann O'Hara offers an even more radical proposal: victim control over the last ro percent of an offender's sentence. ${ }^{32}$ Like McMurray, O'Hara would like to create incentives for apology and reconciliation, specifically, through the mechanism of victim-offender mediation (VOM). ${ }^{33}$ Giving a victim some direct control over an offender's release date from prison would encourage the offender to participate in VOM. Moreover, O'Hara argues, such control would enhance the healing process for some victims by giving them a feeling of being "re-empowered." 34

The articles in this issue thus draw our attention to a variety of ways in which the criminal justice system might contribute to victim recovery (financial, psychological, and otherwise) beyond simply bestowing on victims a right to be heard at sentencing. But the scope of the right to be heard is also a contested matter, as highlighted by recent controversies over the incorporation of victims' rights in the United States Sentencing Guidelines and the Federal Rules of Criminal Procedure.

\section{Reform of the Guidelines and Rules of Criminal Procedure}

Included in this issue are statements by Judge Cassell to the Sentencing Commission, urging the adoption of amendments to the Guidelines that would help ensure that victims can be heard "at a meaningful time and in a meaningful manner." 35 In a sentencing regime centered on a voluminous set of detailed rules, like the Guidelines, the official sentencing hearing in court may be far less important in determining the sentence than the "behind-the-scenes" interactions between the probation officer and the litigants, which serve to frame the issues for judicial resolution. Thus, the question of the victim's right to speak at the sentencing hearing-much discussed in the previous issue of $F S R^{36}$ - may ultimately matter less than whether the victim can participate in the prehearing dialogue. In essence, Cassell's proposals are directed to making such prehearing participation possible. He would make the presentence report available to victims and require the solicitation of their input. 37

If a sentence is, in any important way, supposed to further victim recovery, then Cassell's proposals seem a sensible way to ensure that the sentencing judge is aware of the victim's individual needs and circumstances in a timely fashion. Likewise, if the sentencing process is intended to support victim healing by giving victims a sense of re-empowerment-a sense that their views really matter-then Cassell's proposals also appear to be appropriate reforms. It must be terribly disempowering for a victim to show up at sentencing prepared to give a statement and then discover that all of the important issues have already been decided. But are these victim-centered objectives really a legitimate basis on which to revise sentencing policy? The critics of enhanced hearing rights for victims contend, among other things, that the intense emotional responses evoked by victims may undermine the goals of rationality and uniformity in sentencing ${ }^{3}$ - goals that have been at the heart of the federal sentencing system for more than two decades. 39

The issue concludes with a pending proposal to amend the Federal Rules of Criminal Procedure in light of the Crime Victims' Rights Act of 2004 (CVRA). $4^{\circ}$ New Rule 6o, expressly dedicated to "Victim's Rights," lies at the heart of the proposal. Rule 6o(a)(3) provides that the "court must permit a victim to be reasonably heard at any public proceeding in the district court concerning release, plea, or sentencing," ${ }^{\mathrm{I}}$ closely tracking the language of an analogous provision of the CVRA. ${ }^{2}$ This rather opaque mandate is supplemented with a number of more specific provisions that echo, but do not go as far as, Judge Cassell's proposed amendments to the Guidelines, including an expanded mandate for probation officers to collect information pertaining to restitution and the deletion of some existing restrictions on the inclusion of victim impact information in the presentence report. ${ }^{43}$ Such provisions seemingly contemplate that sentences will take into account the individual needs and circumstances of victims. The proposed amendments also seek to implement the CVRA's mandate that victim privacy be protected, 44 as by reversing a presumption in favor of the disclosure of the address and telephone number of certain victim-witnesses and by requiring a court order before service of a subpoena seeking personal or confidential victim information from a third party. 45 
Not surprisingly, Judge Cassell has proposed his own set of amendments to the Federal Rules that are considerably more protective of victim interests. ${ }^{46}$ Perhaps most notably, in keeping with his emphasis on timely participation in the criminal process, and recognizing that plea agreements often play a crucial role in setting the parameters on the final disposition of a case, Cassell would amend Rule II such that prosecutors would be required to consider victim views during plea negotiations and affirmatively advise the court of victim objections to proposed agreements. 47 Underscoring the implicit recognition that prosecutors do not always take victim interests to heart, Cassell would also provide explicit authority for judges to appoint counsel for victims. $4^{8}$

The various Cassell proposals envision a three-sided form of criminal procedure, with victims taking their place alongside prosecutors and defendants in ways that call to mind the system of collateral prosecution in Germany. As actors in the criminal justice system, victims are recognized in these proposals as having interests that are legitimate, diverse (e.g., restitution, privacy, and participation), and potentially divergent from those of prosecutors. Not squarely addressed, however, is the potential tension (noted by Walther) between the advancement of victim interests and the traditional purposes of criminal punishment (deterrence, retribution, incapacitation, and rehabilitation), much less the tension with the goal of uniform treatment of defendants that has received so much emphasis in recent years. Introducing Cassell's reforms, for instance, into the world of Raeder's domestic violence victims, with all of their diverse needs and desires, would surely exacerbate sentencing disparities - unless we are to assume that prosecutors and judges, having been commanded to solicit victim input, would systematically ignore it, which cannot be a result that proponents of victims' rights would find entirely pleasing.

\section{Reimagining Victims' Rights}

\section{A. The Equal Rights Paradigm}

Advocates often characterize the victims' rights movement as a new civil rights movement, 49 presenting their reform agenda as a matter of equalizing victim and defendant rights. Thus, the CVRA was presented as a means to "counterbalance" defendant rights with new victim rights..$^{\circ}$ This is good politics. Equal treatment under law is a compelling value in our society, and when an inequality is seen as favoring "bad" defendants at the expense of "good" victims, it cries out even more loudly for a legislative response. The civil rights analogy, however, ultimately provides a poor foundation for a comprehensive reform agenda that will truly advance victim interests in the criminal justice system. The interests and circumstances of victims and defendants in criminal litigation diverge so dramatically from one another that the notion of "equal rights" quickly loses meaning. Defendant concerns will typically center on potential state deprivations of property, liberty, and, in some cases, even life. Victims, of course, are not subject to these sorts of litigation risks; their concerns are also important but are apt to be quite different and often far more inchoate. The equal rights ideal is about equal treatment of the similarly situated; victims and defendants, however, are not similarly situated.

Indeed, for that reason, a reform agenda built on equal rights will ultimately deliver both too much and too little to victims. On the one hand, it will deliver "rights" that are of little interest to most victims, or whose social costs likely far exceed victim benefits (e.g., a right for indigent victims to have court-appointed counsel at several different "critical stages" throughout the criminal litigation process; a right to insist on grand jury review of the evidence; or a right to participate in the questioning and removal of potential jurors). On the other hand, it will miss important opportunities for improving the lives of victims that do not have clear parallels in the world of defendant rights, such as financial reparations, apology, mediated victim-offender dialogue, protection of identity and personal privacy, psychological counseling, and protective or rehabilitative measures to prevent revictimization. Notwithstanding the "counterbalancing of defendant rights" rhetoric surrounding passage of the CVRA, this issue and the prior issue of FSR highlight the extent to which victims and their supporters are demanding, and government authorities are providing, assistance in areas that do not fit the equal rights paradigm..$^{5}$

\section{B. Legalism versus Harm-Reductionism}

There is a better way of thinking about recent and proposed victim-centered reforms than in terms of counterbalancing and equal rights, and this alternative paradigm has broader implications for the criminal justice system than the simple addition of a new "party" (the victim) to the existing procedural framework. In order to develop these points, I will borrow some language from the field of 
drug policy. In that field, commentators have long recognized a basic divide between "legalist" and "harm-reductionist" schools of thought. ${ }^{2}$ Legalists draw strict distinctions between legal and illegal drug use, heap moral condemnation on illegal use, and emphasize strong and consistent law enforcement responses to deter illegal use and reinforce law-based moral norms. On this view, the job of the legal system, is simply to administer sanctions in a clear, predictable manner; assuming this job is being done, the operation of the legal system is viewed as essentially unproblematic. Harm-reductionists, by contrast, eschew moral condemnation and the strict legal/illegal dichotomy; favor a more complicated set of distinctions based on the varying health effects of different forms of drug use; emphasize the minimization of overall public health harms through multipronged strategies of interdiction, education, and treatment; and recognize that law enforcement and legal processes themselves cause harms that should also be minimized. On this view, predictable sanctioning may or may not be a sign of a well-functioning legal system, depending on the severity of the sanctions and their contribution to overall harm minimization. While federal drug policy sometimes endorses aspects of the harm-reductionist program, the dominant emphasis since at least the early I980 has been on the legalist side. 53

Given the central place of drug enforcement in the overall federal law enforcement picture, it should not be surprising that federal criminal justice has, as a whole, also embodied the legalist approach since the ig80s. Nowhere is this orientation clearer than in sentencing law, where a host of mandatory minimum statutes and the Sentencing Guidelines (also mandatory until very recently) have emphasized predictable, consistent, and harsh sanctioning of illegal conduct. 54 In recent years, federal sentencing policy has endorsed deterrence (and, perhaps to a somewhat lesser extent, retribution and incapacitation) over rehabilitation. 55 The principal grounds for lenience recognized in the Guidelines (the substantial assistance departure and an "acceptance of responsibility" adjustment that largely functions as a reward for guilty pleas) are justified as incentives for defendants to cooperate with prosecutors and thereby enhance the overall efficiency and effectiveness of law enforcement. All of this reflects underlying values and suppositions that, in the drug policy arena, would plainly be regarded as legalist.

\section{Victim-Based Reforms as Harm Reduction}

A victims' welfare agenda is fundamentally inconsistent with the legalist stance. To be sure, the difficulties melt away if certain common assumptions are made: victims care only about maximizing punishment; victim participation does not really affect outcomes, except perhaps to increase punishment; victim preferences only rarely diverge from those of prosecutors; victim needs and desires are uniform and predictable; and victim conduct is almost always profoundly less blameworthy than offender conduct. As described above, however, the articles in this issue cast doubt on each of the standard victim stereotypes. And once we dispense with the stereotypes, we must recognize that legalist responses to crime will not always, perhaps not even usually, do a good job of serving victim interests. Where the offender is a family member or loved one, the victim may prefer a rehabilitative response. Where the victim has suffered financial harm and the offender is employed, the victim may prefer community-based sanctions that permit the offender to keep his job and make financial reparations. Many victims report substantial psychological benefits from dialogue, explanation, and apology, but offenders are often reluctant to participate in mediation without the prospect of mitigated punishment. Other victims just want to be left alone but, as a result of a prosecutor's law enforcement agenda, become entangled in legal proceedings that are time-consuming, stressful, and potentially embarrassing. In these and many other scenarios, the accommodation of victim needs or preferences may undercut the predictability, certainty, and severity of punishment..$^{6}$

By contrast, the victims' agenda is, I think, quite consistent with the harm-reduction type of thinking. Law enforcement and punishment are not recognized as the sole legitimate response to crime: counseling, reparations, mediation, and the like may also have appropriate places in a multipronged set of social responses. Moreover, the operation of the legal system itself is recognized as a potential source of harm, as when victims lose their privacy or are excluded from trials they wish to attend. The victims' movement thus insists that the law should seek to minimize not only the frequency of private criminal conduct but also the harms arising from the conduct of state actors seeking to punish criminals. ${ }^{57}$ In this vein, even basic hearing rights, such as a right to victim allocution at sentencing, can be understood within the harm-reduction paradigm as facilitating the healing process for victims. Indeed, proponents of victims' rights often speak of the right to be heard in precisely these terms..$^{8}$ 
Viewed in harm-reduction terms, I find the victims' rights movement a refreshing break from the intensely legalist tenor of federal criminal justice. It is beyond the scope of these Editor's Observations to offer a thorough critique of legalism in criminal law, but, by simply pointing to the rapid increase in American prison populations over the past three decades to their current, unprecedented levels, I can give some idea of the direction in which such a critique might head. 59

I recognize that I am taking a rather unconventional and counterintuitive position in suggesting that the victims' rights movement might ultimately do anything to improve the lot of defendants. A more complete elaboration of these ideas will, again, have to await another day, but here are a few preliminary thoughts. First, harm-reducing policies in the victims area highlight the anomaly of sentencing laws that generally decline to make allowances for offenders' family responsibilities. ${ }^{60}$ Yet, as Myrna Raeder observes in this issue, the offender's family members may suffer the most from such laws ${ }^{6}$ - and the family members may be at least as innocent as the victims of the underlying offense. The more we relax legalism as to victims, the harder it is to defend strict legalism as to family members. Second, a real commitment to financial reparations for victims should lend greater weight to calls for greater use of intermediate sanctions that permit offenders to remain in the community and earn income at rates far exceeding prison wages. Third, victims who are made to feel disempowered and disrespected by the legal system are, I suspect, particularly likely to demand harsh punishment when they finally have their chance to speak at sentencing. By contrast, victims may be less inclined to request long sentences, and more inclined to support lenience, when they have been given meaningful opportunities to be heard throughout the criminal process; treated with respect by police, prosecutors, and court personnel; provided with appropriate social services; and reassured that their financial needs will be addressed to the maximum possible extent through restitution awards. And these tendencies will likely be stronger still if the victim has also had an opportunity to participate in a mediated dialogue with the offender. Finally, as prosecutors and judges develop a greater sense of responsibility for victim well-being, they cannot help but notice with concern that a great many offenders have significant incidents of victimization in their past. It is not implausible, in a system that emphasizes legalism less and compassion more, that prosecutors and judges will take more seriously the profound human costs of unnecessarily long prison sentences.

\section{Conclusion}

The victims' movement is unlikely to be transformative in these sorts of ways as long as its agenda is understood to be one of counterbalancing defendant rights. And the equal rights rhetoric has certainly been quite successful in the past for pro-victim reformers. As victim expectations increase, however, victims may increasingly demand services and opportunities that do not really square with the equal rights paradigm. ${ }^{62}$ Over the long run, victims may be best served by a reform agenda that emphasizes responses to crime that are constructive, flexible, and compassionate, emphasizing the meeting of particularized human needs over abstract principles like retribution and general deterrence.

To be sure, this sort of thinking about crime has not had much currency at the federal level for many years. Yet, this does not mean harm-reductionism is wholly lacking in political viability. At the state level, over the past decade, there has been widespread acceptance of such innovations as victim-offender mediation and drug treatment courts. ${ }^{6} 3$ For that matter, many jurisdictions have never gotten around to abolishing parole, which sits uncomfortably within the legalist paradigm, or otherwise maintain sentencing systems that are substantially more discretionary than the federal system, thereby providing judges with more freedom to take into account harm-reduction considerations like family responsibilities.

Legalism, of course, has its place. A system with too much flexibility and case-specific problem solving, no matter how well intentioned, may have the appearance of arbitrariness, which may sap public confidence and undermine crime prevention goals. ${ }^{64}$ State-level experiences indicate, however, that jurisdictions may go much further toward the incorporation of harm-reduction considerations than has the federal system without provoking political backlash. Victim-minded reformers, intentionally or otherwise, may ultimately help to nudge the federal system down the same path.

\section{Notes}

I am grateful for excellent research assistance from Sonya Bice in connection with this and the previous issue of FSR. I am also grateful for comments on an earlier draft from Scott Moss and Chad Oldfather.

1 See Douglas E. Beloof, Judicial Leadership at Sentencing under the Crime Victims' Rights Act: Judge Kozinski in Kenna and Judge Cassell in Degenhardt, 19 FED. Sent'ING RPTR. 36, 37 (2006) ("If popular and Congressional votes are any measure, victims' rights are as American as apple pie."). 
2 See, e.g., 150 Cong. Rec. H8179 (daily ed. Oct. 6, 2004) (statement of Rep. Sensenbrenner), reprinted in 19 FED. SENT'Ing RPtR. 68, 68 (2006) (observing that victims' rights advocates are "push[ing] for a victims' rights statute to counterbalance the rights provided to the accused under the Constitution"); 150 CONG. REC. S4260. 01 (daily ed. April 22, 2004) (statement of Sen. Feinstein), reprinted in 19 FED. SENT'ING RPTR. 62, 63 (2006) ("We offer this legislation [the Crime Victims' Rights Act] because the scales of justice are out of balancewhile criminal defendants have an array of rights under law, crime victims have few meaningful rights.").

3 Michael M. O'Hear, Punishment, Democracy, and Victims, 19 Fed. Sent'Ing Rptr. 1, 2 (2006).

4 See supra note 2.

5 See, e.g., 18 U.S.C. § 3553(a) (setting forth mandates for sentencing).

6 Wayne A. Logan, Victim Impact Evidence in Federal Capital Trials, 19 Fed. Sent'Ing Rptr. 5, 6-9 (2006).

7 Bryan Myers, Emalee Weidemann \& Gregory Pearce, Psychology Weighs in on the Debate Surrounding Victim Impact Statements and Capital Sentencing: Are Emotional Jurors Really Irrational?, 19 FED. SENT'ING RPTR. 13 (2006).

8 Steven J. Twist, Kenna v. District Court, 19 Fed. Sent'Ing RPtr. 30 (2006).

9 Amy Baron-Evans, Traps for the Unwary under the Crime Victims' Rights Act: Lessons from the Kenna Cases, 19 FED. Sent'Ing RPtR. 49, 53-54 (2006).

10 See, e.g., Letter from Amy Baron-Evans \& Mark Flanagan, Practitioners' Advisory Group, to Ricardo Hinojosa, Chair, United States Sentencing Commission (Feb. 28, 2005), reprinted in 19 FED. SENT'ING RPTR. 138 (2006).

11 Myrna S. Raeder, Domestic Violence in Federal Court: Abused Women as Victims, Survivors, and Offenders, 19 FED. SENT'ING RPTR. 91 (2006).

12 Id. at 95.

13 Id. at 97.

14 Id. at 92,100

15 Id. at 92.

16 Id. at 100

17 Marilyn Peterson Armour \& Mark S. Umbreit, Exploring "Closure" and the Ultimate Penal Sanction for Survivors of Homicide Victims, 19 Fed. Sent'Ing RPTR. 105 (2006).

18 For a recent personal statement of opposition to the death penalty by a prominent victims' rights advocate whose daughter was murdered, see Roberta Roper, Finding Hope: One Family's Journey, in WoundS THAT Do Not Bind: Victim-Based Perspectives on the Death Penalty 111, 124-25 (James R. Acker \& David R. Karp eds., 2006).

19 Susanne Walther, Victims' Rights in the German Court System, 19 FEd. Sent'ING RPTR. 113 (2006).

20 Id. at 114 . For an argument that such representation is also now available in the American federal system pursuant to the Crime Victims' Rights Act of 2004, see Russell P. Butler, What Practitioners and Judges Need to Know Regarding Crime Victims' Participatory Rights in Federal Sentencing Proceedings, 19 FED. SENT'ING RPTR. 21, 24 (2006).

21 Walther, supra note 19 , at 113.

22 Id. at 116.

23 Id. at 113

24 Id.

25 Paul G. Cassell, Crime Shouldn't Pay: A Proposal to Create an Effective and Constitutional Federal Anti-profiting Statute, 19 FEd. SENT'ING RPtR. 119 (2006).

26 Id. at $122 \cdot 23$.

27 Id. at 122 (emphasis added).

28 Walther, supra note 19 , at $113,115$.

29 For instance, when an offender is incarcerated, the offender's resulting loss of income may preclude satisfaction of a restitution award.

30 Benji McMurray, The Mitigating Power of a Victim Focus at Sentencing, 19 FEd. SENT'ING RPtR. 125 (2006).

31 Id. at 128

32 Erin Ann O'Hara, Victims and Prison Release: A Modest Proposal, 19 Fed. Sent'Ing Rptr. 130 (2006).

33 Id. at 133.

34 Id. at 132

35 Statement of Paul G. Cassell, Professor of Law, Before the United States Sentencing Commission (Feb. 15, 2005), reprinted in 19 FED. SENT'ING RPTR. 136, 136 (2006) (quoting Fuentes v. Shevin, 407 U.S. 67,80 (1972)).

36 See, e.g., Twist, supra note 8; Richard A. Bierschbach, Allocution and the Purposes of Victim Participation under the CVRA, 19 FEd. SENT'ING RPtR. 44 (2006).

37 Statement of Paul G. Cassell, Professor of Law, Before the United States Sentencing Commission (March 15, 2006), reprinted in 19 FED. SEnT'Ing RPtR. 140, 140-41 (2006).

38 See, e.g., Letter from Amy Baron-Evans \& Mark Flanagan, Practitioners' Advisory Group to the United States Sentencing Commission, to Ricardo Hinojosa, Chair, United States Sentencing Commission (Feb. 28, 2005), reprinted in 19 FED. SENT'ING RPTR. 138, 139 (2006) (noting “the potential for inaccuracy where victims are emotionally involved"); Myers et al., supra note 7, at 17 ("[T]here is ample evidence to support the fear that jurors [exposed to victim impact statements in capital cases] may not consider all evidence fully and that this may lead to capricious judgments.").

39 Michael M. O'Hear, The Original Intent of Uniformity in Federal Sentencing, 74 U. CIN. L. REv. 749,751 (2006).

40 Memorandum from Federal Judicial Conference's Advisory Committee on the Federal Rules of Criminal Pro. cedure to Standing Committee on the Rules of Practice and Procedure (Dec. 8, 2005, as revised on Aug. 1 , 
2006), reprinted in 19 FED. SENT'ING RPTR. 144 (2006) [hereinafter FRCP Proposal; specific page citations will be made to the Proposal as reprinted in this issue of FSR].

41 ld. at 149.

42 See 18 U.S.C. $\S 3771$ (a)(4). The CVRA is excerpted at 19 FED. SENT'ING RPTR. 73 (2006).

43 FRCP Proposal, supra note 40, at 148.

4418 U.S.C. $\S 3771(a)(8)$.

45 FRCP Proposal, supra note 40, at 147.

46 Paul G. Cassell, Recognizing Victims in the Federal Rules of Criminal Procedure: Proposed Amendments in Light of the Crime Victims' Rights Act, 2005 B.Y.U. L. Rev. 835.

47 Id. at 868-69.

48 Id. at 912

49 See, e.g., Twist, supra note 8, at 33 n.4 (characterizing lyrics of Bob Dylan civil rights anthem as applicable to victims' rights).

50 See supra note 2.

51 The CVRA itself, for instance, offers victims not only hearing rights but also rights to "be reasonably pro. tected from the accused," provided with "full and timely restitution," and "treated with . . . respect for ... . privacy." 18 U.S.C. $\$ 3771(a)(1)$, (6), (8). Likewise, the Attorney General Guidelines for Victim and Witness Assistance, revised in 2005 and reprinted in part in the last issue of $F S R$, require that federal investigative agents inform victims of places where they may obtain medical and social services, the availability of restitution, counseling programs, and the availability of special federally funded services for victims of sexual assault and domestic violence. 19 FED. SENT'ING RPTR. 78, 80 (2006). Pending amendments to the Federal Rules of Criminal Procedure are also directed to protecting victim privacy and restitution opportunities. FRCP Proposal, supra note 40, at 147.48. The extraordinary growth and success of victim-offender mediation programs over the past two decades also testify to the desire of many victims for dialogue and apology. See O'Hara, supra note 32, at 131; Bierschbach, supra note 36, at 46.

52 I adapt this discussion from my article Federalism and Drug Control, 57 VAND. L. REV. 783, 789-91 (2004), which, in turn, drew heavily on Franklin E. Zimring and Gordon Hawkins's book THE SEARCH FOR RATIONAL DRUG CONTROL (1992).

53 O'Hear, supra note 52, at 804-5.

54 O'Hear, supra note 39 , at 797.800 .

55 Id. at 783, 786-87.

56 For a more thorough discussion of the tensions between victim-offender mediation and deterrence- or retributionbased sentencing, see Michael M. O'Hear, Is Restorative Justice Compatible with Sentencing Uniformity?, 89 MARQ. L. REv. 305 (2005).

57 The goal of minimizing "secondary victimization" has played a crucial role in the development of the vic. tims' rights agenda. See, e.g., Douglas Evan Beloof, The Third Model of Criminal Process: The Victim Participation Model, 1999 Utah L. Rev. 289, reprinted in Douglas E. Beloof et al., Victims in Criminal Procedure 38, 41 (2d ed. 2006) (discussing "secondary harm" to victims, "which comes from governmental processes and governmental actors within those processes").

58 See, e.g., S. Rep. No. 108.191 (2003), reprinted in 19 FEd. Sent'Ing RPtR. 58, 59.60 (2006).

59 See O'Hear, supra note 56, at 305-6. I would also cite Professor Whitman's compelling critiques of American retributivism, a phenomenon that overlaps with the legalist stance I have described here. See, e.g., James Q. Whitman, A Plea against Retributivism, 7 Buff. CRIM. L. ReV. 85 (2003).

60 See U.S. Sentencing Guidelines Manual $\S \S 5 H 1.6$ (2004) ("Family ties and responsibilities are not ordinarily relevant in determining whether a departure may be warranted.").

61 Raeder, supra note 11 , at 100.

62 For instance, Roberta Roper, a noted victims' rights activist whose daughter was murdered, recalls her first meeting with the prosecutor in her daughter's case. Knowing that her state legislature had recently enacted a victim impact statement law, she inquired about what victim support services were available through the prosecutor. Roper, supra note 18, at 118 . He had none, but the question itself was a telling indication of how victims may not instinctively recognize distinctions between new hearing rights and other forms of social support.

63 O'Hear, supra note 39, at 816.

64 This concern was a recurring theme in the legislative history of the Sentencing Reform Act of 1984, which gave rise to the Guidelines. Id. at 769-70, 772.73. 